\title{
Synthesis, Crystal Structures and Catalytic Property of Dioxomolybdenum(VI) Complexes Derived from Tridentate Schiff Bases
}

\author{
Xue-Wen Zhu \\ Key Laboratory of Surface \& Interface Science of Henan, School of Material \& Chemical Engineering, \\ Zhengzhou University of Light Industry, Zhengzhou 450002, P.R. China \\ *Corresponding author: E-mail: zhuxuewen2017@126.com
}

Received: $10-07-2018$

\begin{abstract}
A pair of structurally similar new dioxomolybdenum(VI) complexes, $\left[\mathrm{MoO}_{2} \mathrm{~L}^{1}(\mathrm{EtOH})\right] \cdot \mathrm{EtOH}(\mathbf{1})$ and $\left[\mathrm{MoO}_{2} \mathrm{~L}^{2}(\mathrm{MeOH})\right]$ (2), where $\mathrm{L}^{1}$ and $\mathrm{L}^{2}$ are the dianionic form of 2-[(2-hydroxyphenylimino)methyl]-6-methoxyphenol $\left(\mathrm{H}_{2} \mathrm{~L}^{1}\right)$ and 2-ethoxy-6-[(2-hydroxyphenylimino)methyl]phenol $\left(\mathrm{H}_{2} \mathrm{~L}^{2}\right)$, respectively, were prepared and characterized by IR and UV-Vis spectroscopy, as well as single crystal X-ray diffraction. X-ray analyses indicate that the complexes are dioxomolybdenum(VI) species. Complex 1 contains ethanol as co-ligand, and complex 2 contains methanol as co-ligand. The coordination geometry around the Mo atoms can be described as distorted octahedron, with one imino- $\mathrm{N}$ and two phenolate-O of the Schiff base ligand, and one oxo group defining the equatorial plane, and with the other oxo group and one solvent-O occupying the axial positions. The catalytic oxidation property of the complexes with tert-butylhydroperoxide in $\mathrm{CH}_{2} \mathrm{Cl}_{2}$ was studied. Both complexes have excellent catalytic properties on cyclooctene and cyclohexene, and good properties on 1-hexene and 1-octene.
\end{abstract}

Keywords: Schiff base; Dioxomolybdenum complex; Crystal structure; Catalytic property

\section{Introduction}

Schiff base complexes have various catalytic properties, such as ring opening polymerization of cycloalkenes, ${ }^{1}$ oxidation of hydrocarbons, ${ }^{2}$ ring opening of large cycloalkanes, ${ }^{3}$ reduction of ketones to alcohols, ${ }^{4}$ alkylation of allylic substrates, ${ }^{5}$ improve enantioselectivity in the cyclopropanation reactions. ${ }^{6}$ The capability of molybdenum to formation of complexes with oxygen-, nitrogen-, and sulfur-containing ligands led to development of molybdenum Schiff base complexes which are efficient catalysts both in homogeneous and heterogeneous reactions. ${ }^{7}$ The properties of the complexes vary obviously with the different types of ligands and coordination sites. Recently, we<smiles>[X]c1cccc(/C=N/c2ccccc2O)c1O</smiles>

Scheme 1. $\mathrm{H}_{2} \mathrm{~L}^{1}: \mathrm{X}=\mathrm{OMe} ; \mathrm{H}_{2} \mathrm{~L}^{2}: \mathrm{X}=\mathrm{OEt}$ have reported a molybdenum complex with hydrazone ligand and its catalytic property. ${ }^{8}$ In the present work, two new dioxomolybdenum(VI) complexes with Schiff base ligands 2-[(2-hydroxyphenylimino)methyl]-6-methoxyphenol $\left(\mathrm{H}_{2} \mathrm{~L}^{1}\right)$ and 2-ethoxy-6-[(2-hydroxyphenylimino) methyl]phenol $\left(\mathrm{H}_{2} \mathrm{~L}^{2}\right.$; Scheme 1$),\left[\mathrm{MoO}_{2} \mathrm{~L}^{1}(\mathrm{EtOH})\right] \cdot \mathrm{EtOH}$ (1) and $\left[\mathrm{MoO}_{2} \mathrm{~L}^{2}(\mathrm{MeOH})\right](2)$, are presented.

\section{Experimental}

\section{1. Materials and Methods}

3-Methoxysalicylaldehyde, 3-ethoxysalicylaldehyde, 2-aminophenol and $\mathrm{MoO}_{2}(\mathrm{acac})_{2}$ were purchased from Sigma-Aldrich and used as received. All other reagents were of analytical reagent grade. The ligands $\mathrm{H}_{2} \mathrm{~L}^{1}$ and $\mathrm{H}_{2} \mathrm{~L}^{2}$ were synthesized according to the literature method with modification. ${ }^{9}$ Elemental analyses of $\mathrm{C}, \mathrm{H}$ and $\mathrm{N}$ were carried out in a Perkin-Elmer automated model 2400 Series II CHNS/O analyzer. FT-IR spectra were obtained on a Perkin-Elmer 377 FT-IR spectrometer with samples prepared as $\mathrm{KBr}$ pellets. UV-Vis spectra were obtained on a 
Lambda 900 spectrometer. X-ray diffraction was carried out on a Bruker APEX II CCD diffractometer. ${ }^{1} \mathrm{H}$ and ${ }^{13} \mathrm{C}$ NMR spectra were recorded on a Bruker $300 \mathrm{MHz}$ instrument.

\section{2. Synthesis of 2-[(2-hydroxyphenylimino) methyl]-6-methoxyphenol $\left(\mathrm{H}_{2} \mathrm{~L}^{\mathbf{1}}\right)$}

3-Methoxysalicylaldehyde $(0.010 \mathrm{~mol}, 1.52 \mathrm{~g})$ and 2-aminophenol ( $0.010 \mathrm{~mol}, 1.10 \mathrm{~g})$ were dissolved in etha$\mathrm{nol}(50 \mathrm{~mL})$. The mixture was stirred for $30 \mathrm{~min}$ to give red solution. Then, the solvent was removed by distillation. The red solid was recrystallized from ethanol to give the Schiff base $\mathrm{H}_{2} \mathrm{~L}^{1}$. Yield: $2.12 \mathrm{~g}(87 \%)$. IR data $\left(\mathrm{cm}^{-1}\right)$ : 3432 $(\mathrm{O}-\mathrm{H}), 1628(\mathrm{C}=\mathrm{N}), 1277(\mathrm{Ar}-\mathrm{O})$. UV-Vis data $\left(\mathrm{CH}_{3} \mathrm{OH}\right.$, $\left.\lambda_{\max }, \mathrm{nm}\right): 267,346,451 .{ }^{1} \mathrm{H}$ NMR (500 MHz, DMSO) $\delta$ $14.02(\mathrm{~s}, 1 \mathrm{H}, \mathrm{OH}), 9.74(\mathrm{~s}, 1 \mathrm{H}, \mathrm{OH}), 8.95(\mathrm{~s}, 1 \mathrm{H}, \mathrm{CH}=\mathrm{N})$, 7.37 (d, 1H, ArH), 7.20-7.07 (m, 3H, ArH), 6.98-6.84 (m, $3 \mathrm{H}, \mathrm{ArH}), 3.81\left(\mathrm{~s}, 3 \mathrm{H}, \mathrm{CH}_{3}\right) .{ }^{13} \mathrm{C} \mathrm{NMR}(126 \mathrm{MHz}, \mathrm{DMSO})$ $\delta 161.54,151.80,150.95,148.15,134.47,127.98,123.78$, $119.57,119.48,119.22,117.89,116.49,115.22,55.85$. Anal. calcd. for $\mathrm{C}_{14} \mathrm{H}_{13} \mathrm{NO}_{3}(\%)$ : C, 69.12; $\mathrm{H}, 5.39 ; \mathrm{N}, 5.76$. Found (\%): C, 68.95; H, 5.50; N, 5.83 .

\section{3. Synthesis of 2-ethoxy-6-[(2-hydro- xyphenylimino)methyl]phenol $\left(\mathrm{H}_{2} \mathrm{~L}^{2}\right)$}

3-Ethoxysalicylaldehyde $(0.010 \mathrm{~mol}, 1.66 \mathrm{~g})$ and 2-aminophenol $(0.010 \mathrm{~mol}, 1.10 \mathrm{~g})$ were dissolved in ethanol $(50 \mathrm{~mL})$. The mixture was stirred for $30 \mathrm{~min}$ to give red solution. Then, the solvent was removed by distillation. The red solid was recrystallized from ethanol to give the Schiff base $\mathrm{H}_{2} \mathrm{~L}^{2}$. Yield: $2.33 \mathrm{~g}(91 \%)$. IR data $\left(\mathrm{cm}^{-1}\right): 3435$ $(\mathrm{O}-\mathrm{H}), 1628(\mathrm{C}=\mathrm{N}), 1275(\mathrm{Ar}-\mathrm{O})$. UV-Vis data $\left(\mathrm{CH}_{3} \mathrm{OH}\right.$, $\left.\lambda_{\max }, \mathrm{nm}\right): 270,345,450 .{ }^{1} \mathrm{H}$ NMR $(500 \mathrm{MHz}, \mathrm{DMSO}) \delta$ 13.89 (s, 1H, OH), 9.76 (s, 1H, OH), $8.95(\mathrm{~s}, 1 \mathrm{H}, \mathrm{CH}=\mathrm{N})$, 7.37 (d, 1H, ArH), 7.20-7.03 (m, 3H, ArH), 6.98-6.84 (m, $3 \mathrm{H}, \mathrm{ArH}), 4.07$ (q, $\left.2 \mathrm{H}, \mathrm{CH}_{2}\right), 1.33\left(\mathrm{t}, 3 \mathrm{H}, \mathrm{CH}_{3}\right) .{ }^{13} \mathrm{C} \mathrm{NMR}$ (126 MHz, DMSO) $\delta 161.53,151.80,151.02,147.50$, $134.47,127.96,123.81,118.86,119.48,118.83,117.45$, 116.49, 118.16, 64.87, 14.75. Anal. calcd. for $\mathrm{C}_{15} \mathrm{H}_{15} \mathrm{NO}_{3}$ (\%): C, 70.02; H, 5.88; N, 5.44. Found (\%): C, 70.15; H, $5.96 ; \mathrm{N}, 5.37$.

\section{4. Synthesis of Complex 1}

$\mathrm{H}_{2} \mathrm{~L}^{1}(0.010 \mathrm{~mol}, 2.43 \mathrm{~g})$ and $\mathrm{MoO}_{2}(\mathrm{acac})_{2}(0.010$ $\mathrm{mol}, 2.65 \mathrm{~g})$ were mixed and dissolved in ethanol $(50 \mathrm{~mL})$. The mixture was stirred for $1 \mathrm{~h}$ to give yellow solution. Single crystals of the complex, suitable for X-ray diffraction, were grown from the solution upon slowly evaporation for a few days. Yield: $1.87 \mathrm{~g}(41 \%)$. IR data $\left(\mathrm{cm}^{-1}\right)$ : $3357(\mathrm{O}-$ $\mathrm{H}), 1612(\mathrm{C}=\mathrm{N}), 1263(\mathrm{Ar}-\mathrm{O}), 929$ and $910(\mathrm{Mo}=\mathrm{O})$. UVVis data $\left(\mathrm{CH}_{3} \mathrm{OH}, \lambda_{\max }, \mathrm{nm}\right): 273,330$. Anal. calcd. for $\mathrm{C}_{18} \mathrm{H}_{23} \mathrm{MoNO}_{7}$ (\%): C, 46.86; H, 5.03; N, 3.04. Found (\%): C, 46.67; H, 4.89; N, 3.13 .

\section{5. Synthesis of Complex 2}

$\mathrm{H}_{2} \mathrm{~L}^{2}$ (0.01 mol, $\left.2.57 \mathrm{~g}\right)$ and $\mathrm{MoO}_{2}(\mathrm{acac})_{2}(0.01 \mathrm{~mol}$, $2.65 \mathrm{~g})$ were mixed and dissolved in methanol $(50 \mathrm{~mL})$. The mixture was stirred for $1 \mathrm{~h}$ to give yellow solution. Single crystals of the complex, suitable for X-ray diffraction, were grown from the solution upon slowly evaporation for a few days. Yield: $2.12 \mathrm{~g}(51 \%)$. IR data $\left(\mathrm{cm}^{-1}\right): 3382(\mathrm{O}-$ $\mathrm{H}), 1611(\mathrm{C}=\mathrm{N}), 1267(\mathrm{Ar}-\mathrm{O}), 930$ and $912(\mathrm{Mo}=\mathrm{O})$. UVVis data $\left(\mathrm{CH}_{3} \mathrm{OH}, \lambda_{\max }, \mathrm{nm}\right): 275,330$. Anal. calcd. for $\mathrm{C}_{16} \mathrm{H}_{17} \mathrm{MoNO}_{6}(\%)$ : C, 46.28; H, 4.13; N, 3.37. Found (\%): C, 46.10; H, 4.07; N, 3.51.

\section{6. X-ray Crystallography}

$\mathrm{X}$-ray diffraction was carried out at a Bruker APEX II CCD area diffractometer equipped with MoKa radiation $(\lambda=0.71073 \AA)$. The collected data were reduced with SAINT, ${ }^{10}$ and multi-scan absorption correction was performed using SADABS. ${ }^{11}$ The structures of the complexes were solved by direct method, and refined against $F^{2}$ by full-matrix least-squares method using SHELXTL. ${ }^{12}$ All of the non-hydrogen atoms were refined anisotropically. The hydrogen atoms were placed in calculated positions and constrained to ride on their parent atoms. The crystallographic data and refinement parameters for the complexes

Table 1. Crystallographic and refinement data for the complexes

\begin{tabular}{|c|c|c|}
\hline & 1 & 2 \\
\hline Formula & $\mathrm{C}_{18} \mathrm{H}_{23} \mathrm{MoNO}_{7}$ & $\mathrm{C}_{16} \mathrm{H}_{17} \mathrm{MoNO}_{6}$ \\
\hline Formula weight & 461.31 & 415.25 \\
\hline Crystal shape/color & Block/yellow & Block/yellow \\
\hline$T(\mathrm{~K})$ & $298(2)$ & $298(2)$ \\
\hline $\begin{array}{l}\text { Crystal } \\
\text { dimensions }\left(\mathrm{mm}^{3}\right)\end{array}$ & $0.23 \times 0.22 \times 0.18$ & $0.27 \times 0.27 \times 0.22$ \\
\hline Crystal system & Monoclinic & Monoclinic \\
\hline Space group & $P 2_{1} / c$ & $P 2_{1} / c$ \\
\hline$a(\AA)$ & $8.3857(11)$ & $10.0718(10)$ \\
\hline$b(\AA)$ & $6.9208(12)$ & $18.1333(12)$ \\
\hline$c(\AA)$ & $34.0235(15)$ & $19.234(2)$ \\
\hline$\beta\left({ }^{\circ}\right)$ & $91.317(2)$ & $97.354(2)$ \\
\hline$V\left(\AA^{3}\right)$ & $1967.7(4)$ & $3483.9(6)$ \\
\hline$Z$ & 4 & 8 \\
\hline$D_{\text {calc }}\left(\mathrm{g} \mathrm{cm}^{-3}\right)$ & 1.557 & 1.583 \\
\hline$\mu(\mathrm{Mo} \mathrm{Ka})\left(\mathrm{mm}^{-1}\right)$ & 0.705 & 0.783 \\
\hline$F(000)$ & 944 & 1680 \\
\hline Measured reflections & 9054 & 20401 \\
\hline Unique reflections & 3611 & 6469 \\
\hline $\begin{array}{l}\text { Observed } \\
\text { reflections }(I \geq 2 \sigma(I))\end{array}$ & 2385 & 5125 \\
\hline Parameters & 251 & 443 \\
\hline Restraints & 1 & 5 \\
\hline Goodness of fit on $F^{2}$ & 1.135 & 1.093 \\
\hline$R_{1}, w R_{2}[I \geq 2 \sigma(I)]^{a}$ & $0.0896,0.1551$ & $0.0395,0.1001$ \\
\hline$R_{1}, w R_{2}(\text { all data })^{a}$ & $0.1393,0.1742$ & $0.0549,0.1096$ \\
\hline
\end{tabular}


Table 2. Selected bond distances $(\AA)$ and angles $\left(^{\circ}\right)$ for the complexes.

\begin{tabular}{|c|c|c|c|}
\hline \multicolumn{4}{|c|}{1} \\
\hline $\mathrm{Mo}(1)-\mathrm{O}(1)$ & $1.919(6)$ & $\mathrm{Mo}(1)-\mathrm{O}(2)$ & $1.950(6)$ \\
\hline $\mathrm{Mo}(1)-\mathrm{O}(4)$ & $2.315(7)$ & $\mathrm{Mo}(1)-\mathrm{O}(5)$ & $1.683(6)$ \\
\hline $\mathrm{Mo}(1)-\mathrm{O}(6)$ & $1.708(6)$ & $\mathrm{Mo}(1)-\mathrm{N}(1)$ & $2.255(7)$ \\
\hline $\mathrm{O}(5)-\mathrm{Mo}(1)-\mathrm{O}(6)$ & $103.8(3)$ & $\mathrm{O}(5)-\mathrm{Mo}(1)-\mathrm{O}(1)$ & $98.6(3)$ \\
\hline $\mathrm{O}(6)-\mathrm{Mo}(1)-\mathrm{O}(1)$ & $100.7(3)$ & $\mathrm{O}(5)-\mathrm{Mo}(1)-\mathrm{O}(2)$ & $97.8(3)$ \\
\hline $\mathrm{O}(6)-\mathrm{Mo}(1)-\mathrm{O}(2)$ & $97.6(3)$ & $\mathrm{O}(1)-\mathrm{Mo}(1)-\mathrm{O}(2)$ & $151.7(3)$ \\
\hline $\mathrm{O}(5)-\mathrm{Mo}(1)-\mathrm{N}(1)$ & $92.7(3)$ & $\mathrm{O}(6)-\mathrm{Mo}(1)-\mathrm{N}(1)$ & $162.7(3)$ \\
\hline $\mathrm{O}(1)-\mathrm{Mo}(1)-\mathrm{N}(1)$ & $81.6(3)$ & $\mathrm{O}(2)-\mathrm{Mo}(1)-\mathrm{N}(1)$ & 74.7(3) \\
\hline $\mathrm{O}(5)-\mathrm{Mo}(1)-\mathrm{O}(4)$ & $170.1(3)$ & $\mathrm{O}(6)-\mathrm{Mo}(1)-\mathrm{O}(4)$ & $86.0(3)$ \\
\hline $\mathrm{O}(1)-\mathrm{Mo}(1)-\mathrm{O}(4)$ & $80.8(3)$ & $\mathrm{O}(2)-\mathrm{Mo}(1)-\mathrm{O}(4)$ & 79.1(3) \\
\hline $\mathrm{N}(1)-\mathrm{Mo}(1)-\mathrm{O}(4)$ & $77.4(2)$ & & \\
\hline \multicolumn{4}{|c|}{2} \\
\hline $\mathrm{Mo}(1)-\mathrm{O}(1)$ & $1.975(3)$ & $\mathrm{Mo}(1)-\mathrm{O}(2)$ & $1.951(3)$ \\
\hline $\mathrm{Mo}(1)-\mathrm{O}(4)$ & $1.685(3)$ & $\mathrm{Mo}(1)-\mathrm{O}(5)$ & $1.690(3)$ \\
\hline $\mathrm{Mo}(1)-\mathrm{O}(6)$ & $2.301(3)$ & $\operatorname{Mo}(1)-\mathrm{N}(1)$ & $2.286(3)$ \\
\hline $\mathrm{Mo}(2)-\mathrm{O}(10)$ & $1.684(3)$ & $\mathrm{Mo}(2)-\mathrm{O}(11)$ & $1.691(3)$ \\
\hline $\mathrm{Mo}(2)-\mathrm{O}(8)$ & $1.958(3)$ & $\mathrm{Mo}(2)-\mathrm{O}(7)$ & $1.968(3)$ \\
\hline $\operatorname{Mo}(2)-\mathrm{N}(2)$ & $2.273(3)$ & $\mathrm{Mo}(2)-\mathrm{O}(12)$ & $2.329(3)$ \\
\hline $\mathrm{O}(4)-\mathrm{Mo}(1)-\mathrm{O}(5)$ & $104.70(16)$ & $\mathrm{O}(4)-\mathrm{Mo}(1)-\mathrm{O}(2)$ & $102.31(14)$ \\
\hline $\mathrm{O}(5)-\mathrm{Mo}(1)-\mathrm{O}(2)$ & $95.90(14)$ & $\mathrm{O}(4)-\mathrm{Mo}(1)-\mathrm{O}(1)$ & $95.52(14)$ \\
\hline $\mathrm{O}(5)-\mathrm{Mo}(1)-\mathrm{O}(1)$ & $104.44(14)$ & $\mathrm{O}(2)-\mathrm{Mo}(1)-\mathrm{O}(1)$ & $148.54(12)$ \\
\hline $\mathrm{O}(4)-\mathrm{Mo}(1)-\mathrm{N}(1)$ & $90.80(14)$ & $\mathrm{O}(5)-\mathrm{Mo}(1)-\mathrm{N}(1)$ & $163.45(14)$ \\
\hline $\mathrm{O}(2)-\mathrm{Mo}(1)-\mathrm{N}(1)$ & $74.77(12)$ & $\mathrm{O}(1)-\mathrm{Mo}(1)-\mathrm{N}(1)$ & 79.32(12) \\
\hline $\mathrm{O}(4)-\mathrm{Mo}(1)-\mathrm{O}(6)$ & $169.69(13)$ & $\mathrm{O}(5)-\mathrm{Mo}(1)-\mathrm{O}(6)$ & $84.85(14)$ \\
\hline $\mathrm{O}(2)-\mathrm{Mo}(1)-\mathrm{O}(6)$ & $80.18(12)$ & $\mathrm{O}(1)-\mathrm{Mo}(1)-\mathrm{O}(6)$ & 78.07(11) \\
\hline $\mathrm{N}(1)-\mathrm{Mo}(1)-\mathrm{O}(6)$ & $80.14(12)$ & $\mathrm{O}(10)-\mathrm{Mo}(2)-\mathrm{O}(11)$ & $105.69(18)$ \\
\hline $\mathrm{O}(10)-\mathrm{Mo}(2)-\mathrm{O}(8)$ & $96.57(15)$ & $\mathrm{O}(11)-\mathrm{Mo}(2)-\mathrm{O}(8)$ & $100.16(15)$ \\
\hline $\mathrm{O}(10)-\mathrm{Mo}(2)-\mathrm{O}(7)$ & $102.51(15)$ & $\mathrm{O}(11)-\mathrm{Mo}(2)-\mathrm{O}(7)$ & $98.82(14)$ \\
\hline $\mathrm{O}(8)-\mathrm{Mo}(2)-\mathrm{O}(7)$ & $148.24(12)$ & $\mathrm{O}(10)-\mathrm{Mo}(2)-\mathrm{N}(2)$ & $163.87(15)$ \\
\hline $\mathrm{O}(11)-\mathrm{Mo}(2)-\mathrm{N}(2)$ & $89.44(14)$ & $\mathrm{O}(8)-\mathrm{Mo}(2)-\mathrm{N}(2)$ & $74.83(12)$ \\
\hline $\mathrm{O}(7)-\mathrm{Mo}(2)-\mathrm{N}(2)$ & $80.14(11)$ & $\mathrm{O}(10)-\mathrm{Mo}(2)-\mathrm{O}(12)$ & $84.58(15)$ \\
\hline $\mathrm{O}(11)-\mathrm{Mo}(2)-\mathrm{O}(12)$ & $169.73(14)$ & $\mathrm{O}(8)-\mathrm{Mo}(2)-\mathrm{O}(12)$ & $78.56(13)$ \\
\hline $\mathrm{O}(7)-\mathrm{Mo}(2)-\mathrm{O}(12)$ & $78.24(11)$ & $\mathrm{N}(2)-\mathrm{Mo}(2)-\mathrm{O}(12)$ & $80.38(12)$ \\
\hline
\end{tabular}

are listed in Table 1. Selected bond lengths and angles are listed in Table 2.

\section{7. Catalytic Epoxidation of Olefins}

Epoxidation of cyclooctene, cyclohexene, 1-octene and 1-hexene catalyzed by the complexes with tert-butylhydroperoxide (TBHP) in $\mathrm{CH}_{2} \mathrm{Cl}_{2}$ was carried out according to the following general procedure. To a $25 \mathrm{~mL}$ round bottomed flask equipped with a magnetic stirring bar and immersed into water thermo-stated bath, was added 10 $\mathrm{mL} \mathrm{CH} \mathrm{Cl}_{2}, 1.0 \mathrm{mmol}$ TBHP, $0.01 \mathrm{mmol}$ catalyst and 1.0 $\mathrm{mmol}$ olefin. The mixture was refluxed with vigorous stirring for $2 \mathrm{~h}$ at an appropriately chosen temperature. The progress of the reaction was monitored by carefully withdrawing aliquots of the sample at different time intervals to determine concentrations of the products by GC analysis, using $n$-hexane as an internal standard and was left to proceed until near complete conversion of TBHP. The con- centration of the TBHP was determined by iodometric titration method. ${ }^{13}$ The yield of epoxide (\%) was calculated according to the starting amount of olefin. Assignments of the products were made by comparison with authentic samples. All the reactions were run in triplicates. Control experiments showed that no epoxide was formed in a measurable extent in the absence of catalyst.

\section{Results and Discussion}

\section{1. General}

The Schiff base ligands $\mathrm{H}_{2} \mathrm{~L}^{1}$ and $\mathrm{H}_{2} \mathrm{~L}^{2}$ were readily prepared by the condensation reaction of 2-aminophenol with 3-methoxysalicylaldehyde and 3-ethoxysalicylaldehyde, respectively. The molybdenum(VI) complexes $\mathbf{1}$ and 2 were synthesized by stirring equimolar quantities of the Schiff bases with $\mathrm{MoO}_{2}(\mathrm{acac})_{2}$ in ethanol or methanol at room temperature. Single crystals of the complexes are sta- 
ble in air at ambient condition. The complexes are soluble in methanol, ethanol, acetonitrile, DMSO, DMF, but insoluble in water. The chemical formulae of the complexes have been confirmed by elemental analyses, IR spectra, and single crystal X-ray diffraction.

\section{2. Spectral Characterization}

The bands at $1628 \mathrm{~cm}^{-1}$ characteristic of the azomethine groups present in the free Schiff bases, were shifted to lower wave numbers at $1612 \mathrm{~cm}^{-1}$ for $\mathbf{1}$ and $1611 \mathrm{~cm}^{-1}$ for 2 , indicating that the involvement the azomethine nitrogen atoms in coordination. The bands at 1275-1277 $\mathrm{cm}^{-1}$ in the spectra of the Schiff bases are ascribed to the phenolic $\mathrm{C}-\mathrm{O}$ stretching vibration. These bands are found at 1263 and $1267 \mathrm{~cm}^{-1}$ in the spectra of the complexes. These changes suggest that the hydroxyl groups of the Schiff bases took part in the complex formation. The Schiff bases and the complexes exhibit broad bands at $3300-3400 \mathrm{~cm}^{-1}$, which may be assigned to the $v(\mathrm{O}-\mathrm{H})$. Further evidence of the bonding is also shown by the observation that new bands in the IR spectra of the metal complexes appear at $450-650 \mathrm{~cm}^{-1}$ assigned to Mo-N and $\mathrm{Mo}-\mathrm{O}$ stretching vibrations. The $\mathrm{Mo}=\mathrm{O}$ stretching mode occur as double bands at 930 and $910 \mathrm{~cm}^{-1}$, assigned to the symmetric and asymmetric stretching modes of the $\mathrm{MoO}_{2}$ moieties. ${ }^{14}$

Electronic absorption spectra of the Schiff base and the complexes were obtained in methanol solutions. The electronic absorption spectra of the free Schiff bases displayed three bands at 270,345 and $450 \mathrm{~nm}$, which are assigned for the $\pi \rightarrow \pi^{\star}$ and $n \rightarrow \pi^{\star}$ transitions, respectively. In the electronic spectra of the complexes, the strong bands centered at $273 \mathrm{~nm}$ are attributed to the intra-ligand $\pi \rightarrow \pi^{*}$ absorption peak of the Schiff base ligand. The LMCT and to some extent $\pi \rightarrow \pi^{\star}$ bands appear at about $330 \mathrm{~nm}$.

\section{3. Structural Description of Complex 1}

The molecular structure of complex $\mathbf{1}$ is shown in Figure 1. It contains a dioxomolybdenum complex molecule and an ethanol molecule of crystallization. The coordination geometry around the Mo atom can be described as distorted octahedron, with one imino-N and two phenolate-O of the Schiff base ligand, and one oxo group defining the equatorial plane, and with the other oxo group and one ethanol-O occupying the axial positions. The Schiff base ligand coordinates to the Mo atom in a meridional fashion forming five- and six-membered chelate rings with bite angles of $74.7(3)$ and $81.6(3)^{\circ}$. The dihedral angle between the two benzene rings of the Schiff base ligand is 6.5(3) ${ }^{\circ}$. The $\mathrm{O}=\mathrm{Mo}=\mathrm{O}$ angle $\left(103.8(3)^{\circ}\right)$ and the $\mathrm{Mo}=\mathrm{O}$ distances (1.683(3)-1.708(3) $\AA$ ) are typical for cis-dioxomolybdenum(VI) complexes. ${ }^{7}$ The imino nitrogen and ethanol oxygen atoms, which are trans to the terminal oxo groups, bond to the $\mathrm{Mo}(\mathrm{VI})$ atom with distances of 2.255(7) $\AA$ for nitrogen and 2.315(7) Å for oxygen, respectively. The Mo-O distances vary from 1.919(6) to 1.950(6) $\AA$ for the phenolate oxygen, which are in accord with these types of bonds in hexa-coordinated dioxomolybdenum(VI) complexes. ${ }^{7}$

In the crystal structure of the complex, the $\left[\mathrm{MoO}_{2} \mathrm{~L}^{1}(\mathrm{EtOH})\right]$ complex molecules are linked by ethanol molecules through two intermolecular $\mathrm{O}-\mathrm{H}$... O hydrogen bonds $\left[\mathrm{O}(7)-\mathrm{H}(7 \mathrm{~A})=0.82 \AA, \mathrm{H}(7 \mathrm{~A}) \cdots \mathrm{O}(6)^{\mathrm{i}}=1.91 \AA\right.$, $\mathrm{O}(7) \cdots \mathrm{O}(6)^{\mathrm{i}}=2.725(9) \AA, \mathrm{O}(7)-\mathrm{H}(7 \mathrm{~A}) \cdots \mathrm{O}(6)^{\mathrm{i}}=174(5)^{\circ}$; symmetry code for i: $x, 1+y, z]$, to form one dimensional chains along the $b$ axis (Figure 2).

\section{4. Structural Description of Complex 2}

The molecular structure of complex $\mathbf{2}$ is shown in Figure 3. It contains two dioxomolybdenum complex mol-

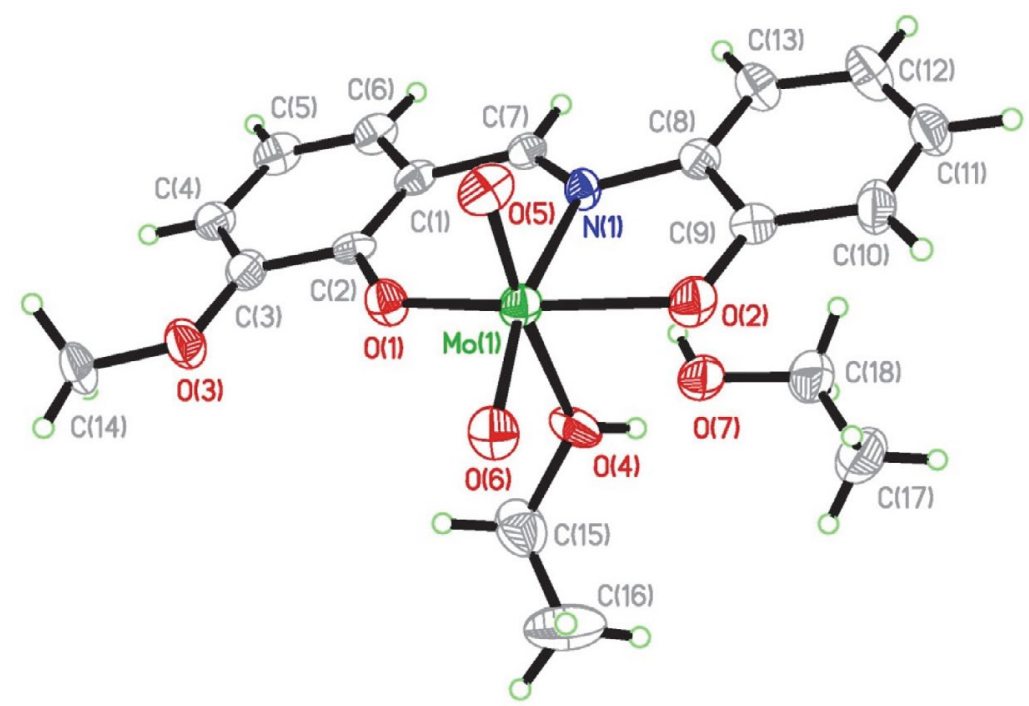

Figure 1. A perspective view of complex 1 with the atom labeling scheme. Thermal ellipsoids are drawn at the $30 \%$ probability level. 


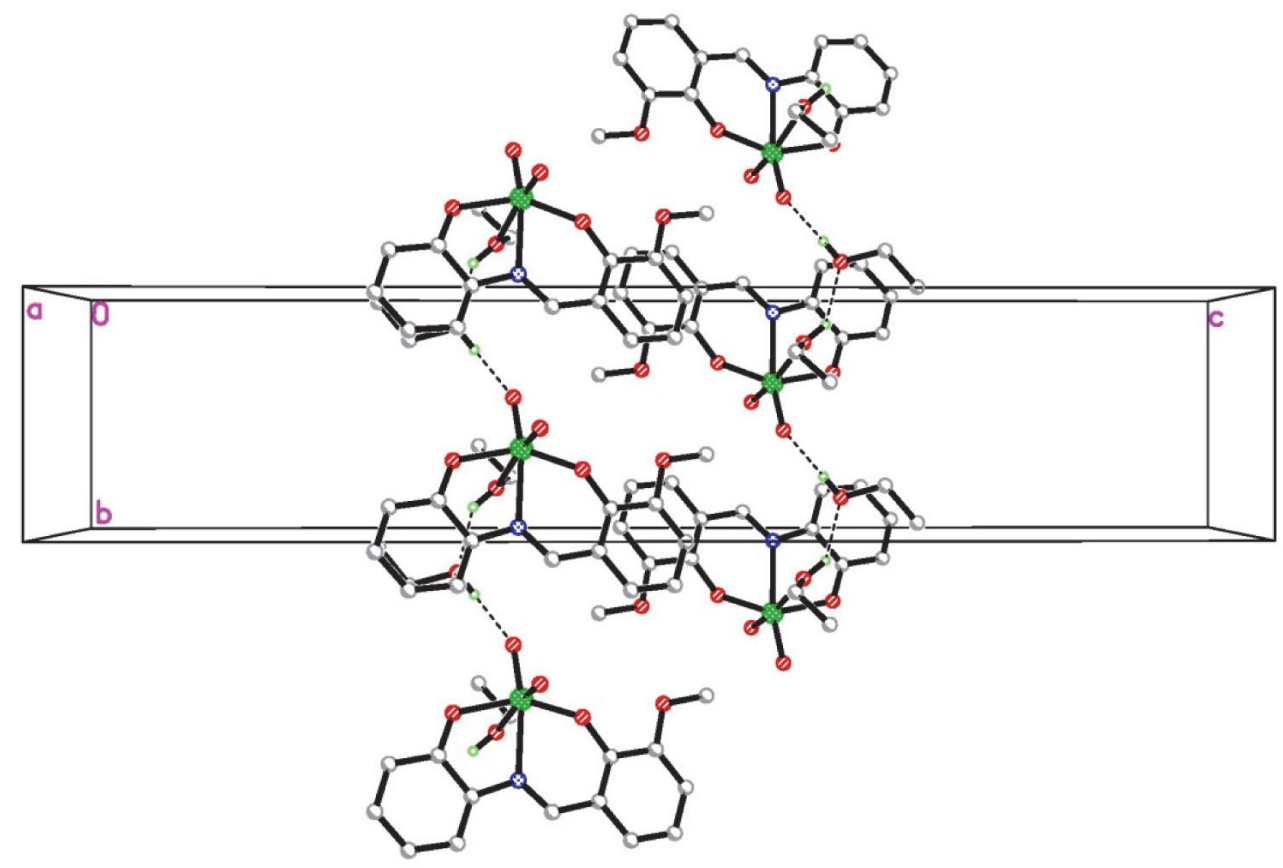

Figure 2. The hydrogen bonds (dashed lines) linked molecules into one dimensional chains of complex $\mathbf{1}$, viewed along the $a$ axis.

ecules in the asymmetric unit. The two complex molecules are linked through $\mathrm{O}-\mathrm{H} \cdots \mathrm{O}$ hydrogen bonds $[\mathrm{O}(12)-\mathrm{H}$ $(12 \mathrm{~A})=0.85(1) \AA, \mathrm{H}(12 \mathrm{~A}) \cdots \mathrm{O}(1)=1.96(2) \AA, \mathrm{O}(12) \cdots \mathrm{O}(1)$ $=2.792(4) \AA, \mathrm{O}(12)-\mathrm{H}(12 \mathrm{~A}) \cdots \mathrm{O}(1)=169(4)^{\circ} ; \mathrm{O}(6)-\mathrm{H}(6)$ $=0.85(1) \AA, \mathrm{H}(6) \cdots \mathrm{O}(7)=1.92(1) \AA, \mathrm{O}(6) \cdots \mathrm{O}(7)=2.776(4)$ $\left.\AA, \mathrm{O}(6)-\mathrm{H}(6) \cdots \mathrm{O}(7)=175(2)^{\circ}\right]$. The coordination geometry around the Mo atom can be described as distorted octahedron, with one imino- $\mathrm{N}$ and two phenolate-O of the Schiff base ligand, and one oxo group defining the equatorial plane, and with the other oxo group and one metha-

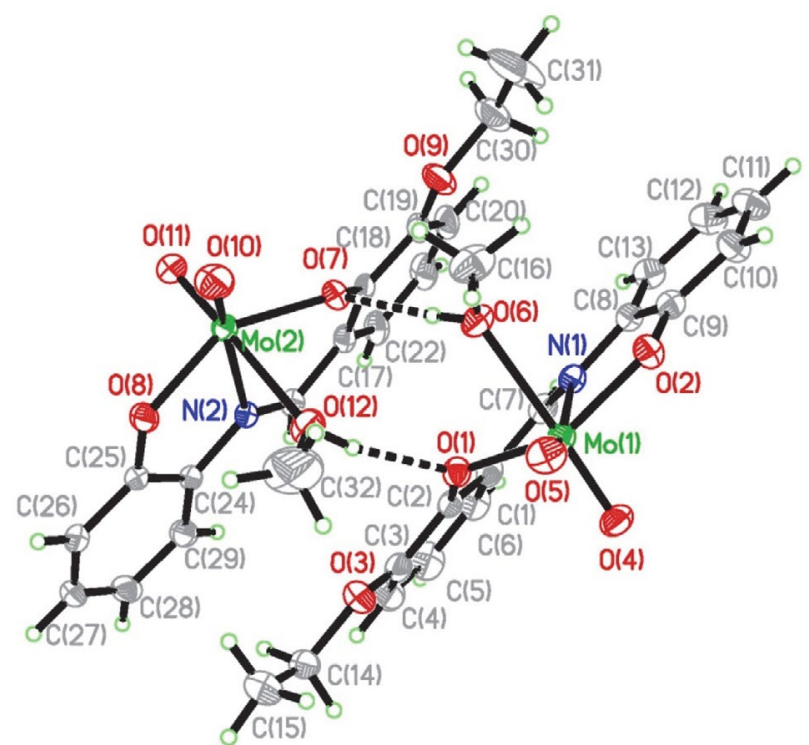

Figure 3. A perspective view of complex 2 with the atom labeling scheme. Thermal ellipsoids are drawn at the $30 \%$ probability level. Hydrogen bonds are shown as dashed lines.
nol-O occupying the axial positions. The Schiff base ligand coordinates to the Mo atom in a meridional fashion forming five- and six-membered chelate rings with bite angles of $74.68(12)$ and $81.67(12)^{\circ}$ for $\mathrm{Mo}(1)$ moiety, and $74.83(12)$ and $80.14(11)^{\circ}$ for $\mathrm{Mo}(2)$ moiety. The dihedral angles between the two benzene rings of the Schiff base ligands are $10.8(5)^{\circ}$ and $6.7(5)^{\circ}$. The $\mathrm{O}=\mathrm{Mo}=\mathrm{O}$ angles $\left(104.70(16)\right.$ and $\left.105.69(18)^{\circ}\right)$ and the $\mathrm{Mo}=\mathrm{O}$ distances (1.684(3)-1.691(3) $\AA$ ) are typical for cis-dioxomolybdenum(VI) complexes. ${ }^{7}$ The imino nitrogen and ethanol oxygen atoms, which are trans to the terminal oxo groups, bond to the $\mathrm{Mo}(\mathrm{VI})$ atom with distances of 2.273(3)-

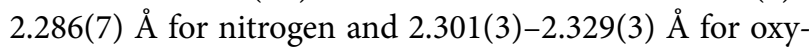
gen, respectively. The Mo-O distances vary from 1.951(3) to 1.975 (3) $\AA$ for the phenolate oxygen, which are in accord with these types of bonds in hexa-coordinated dioxomolybdenum(VI) complexes. ${ }^{7}$ In the crystal structure of the complex, molecules are stack along the $a$ axis (Figure 4).

\section{5. Catalytic property of the Complexes}

Catalytic property of the complexes was investigated in the epoxidation of cyclooctene, cyclohexene, 1-octene and 1-hexene with TBHP and $\mathrm{CH}_{2} \mathrm{Cl}_{2}$ as a solvent at different temperatures 25,45 and $65^{\circ} \mathrm{C}$. The catalytic reactions were initially performed in order to test the performance of the system under the easiest possible reaction conditions. A substrate, oxidant, and catalyst ratio of 100:100:1 was used. In general, the epoxide yields are higher for cyclic olefins than those for terminal olefins. As seen in Table 3 , the order of increasing reactivity based on yield $\%$ are as cyclooctene $>$ cyclohexene $>1$-hexene $>1$-octene. In addition, the ep- 


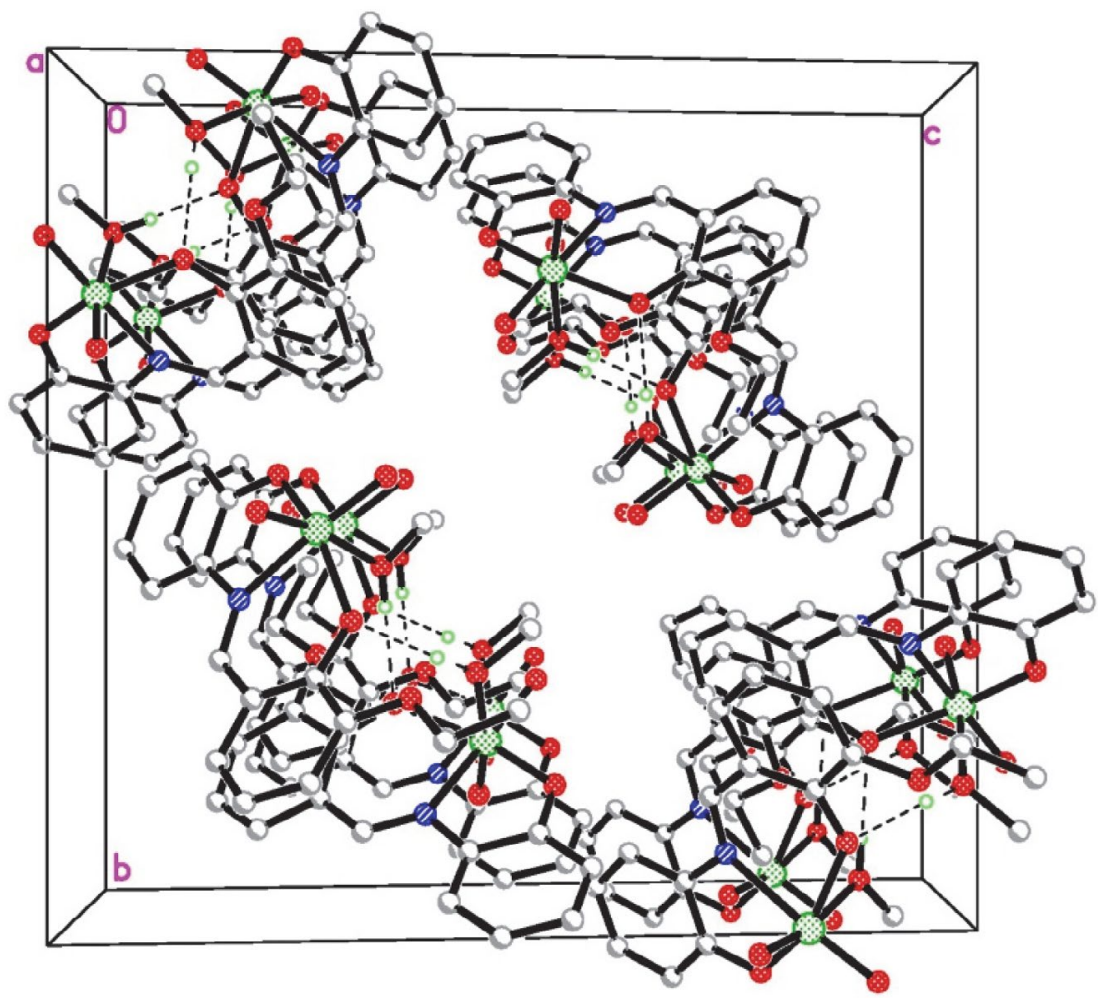

Figure 4. The hydrogen bonds (dashed lines) linked dimeric structure of complex 2, viewed along the $a$ axis.

Table 3. Epoxide yields (\%) for the catalytic processes at different temperatures

\begin{tabular}{lrrrrrr}
\hline Substrate & \multicolumn{2}{c}{$\mathbf{2 5}^{\circ} \mathbf{C}$} & \multicolumn{2}{c}{$\mathbf{4 5}{ }^{\circ} \mathbf{C}$} & \multicolumn{2}{c}{$\mathbf{6 5}{ }^{\circ} \mathbf{C}$} \\
& $\mathbf{1}$ & $\mathbf{2}$ & $\mathbf{1}$ & $\mathbf{2}$ & $\mathbf{1}$ & $\mathbf{2}$ \\
\hline Cyclooctene & 87 & 85 & 93 & 93 & 98 & 97 \\
Cyclohexene & 81 & 81 & 89 & 90 & 94 & 94 \\
1-Hexene & 70 & 73 & 78 & 80 & 85 & 84 \\
1-Octene & 62 & 61 & 70 & 70 & 77 & 75 \\
\hline
\end{tabular}

oxide yields increase with the rise in temperature. Both complexes have similar catalytic properties, because of their similar structures. As a comparison, the catalytic property of the complexes on cyclohexene is similar to the molybdenum complex with tris(hydroxymethyl)amino methane as ligand. ${ }^{15}$ The complexes have in general higher catalytic property on the substrates than the molybdenum complex derived from the Schiff base ligand $N, N^{\prime}$-bis(salicylidene) 4,5-dichloro-1,2-phenylenediamine. ${ }^{7 \mathrm{~d}}$

\section{Conclusion}

Two new dioxomolybdenum(VI) complexes derived from the Schiff base ligands 2-[(2-hydroxyphenylimino) methyl]-6-methoxyphenol and 2-ethoxy-6-[(2-hydroxyphenylimino)methyl]phenol have been prepared and structurally characterized. The Mo atoms in the complexes are in octahedral coordination. Both complexes have ef- fective catalytic properties on cyclooctene and cyclohexene.

\section{Supplementary Material}

CCDC-1849701 and 1849702 contain the supplementary crystallographic data for this paper. These data can be obtained free of charge at http://www.ccdc.cam. ac.uk/const/retrieving.html or from the Cambridge Crystallographic Data Centre (CCDC), 12 Union Road, Cambridge CB2 1EZ, UK; fax: +44(0)1223-336033 or e-mail: deposit@ccdc.cam.ac.uk.

\section{References}

1. D. Huang, C. Wang, Y. Song, Russ. J. Gene. Chem. 2013, 83, 2361-2369. DOI:10.1134/S1070363213120281 
2. (a) S. Biswas, A. Dutta, M. Dolai, M. Debnath, A. D. Jana, M. Ali, RSC Advances 2014, 4, 34248-34256;

DOI:10.1039/C4RA06078D

(b) B. Bahramian, F. D. Ardejani, V. Mirkhani, K. Badii, Appl. Catal. A General 2008, 345, 97-103.

DOI:10.1016/j.apcata.2008.04.028

3. (a) A. Schriescheim, R. J. Muller, C. A. Rowe, J. Am. Chem. Soc. 1962, 84, 3164-3172; DOI:10.1021/ja00875a026

(b) F. Farzaneh, M. Ghiasi, M. Ghandi, M. Ghandi, V. Daadmehr, Porous Mater. 2013, 20, 267-275;

DOI:10.1007/s10934-012-9596-8

(c) K. Pamin, G. Pozzi, E. Tabor, W. Bukowski, J. Poltowicz, Catal. Commun. 2013, 39, 102-105.

4. G. Ventakachalam, R. Ramesh, Inorg. Chem. Commun. 2005, 8, 1009-1013. DOI:10.1016/j.inoche.2005.08.004

5. D. Pou, A. E. Platero-Prats, S. Perez, C. Lopez, X. Solans, M. Font-Bardia, P. W. N. M. van Leeuwen, G. P. F. van Strijdonck, Z. Freixa, J. Organomet. Chem. 2007, 692, 5017-5025.

DOI:10.1016/j.jorganchem.2007.07.027

6. (a) G. Koz, D. Astley, S. T. Astley, Turk. J. Chem. 2011, 35, 553-560;

(b) D. S. Masterson, T. L. Hobbs, D. T. Glatzhofer, J. Mol. Catal. A Chem. 1999, 145, 75-81.

DOI:10.1016/S1381-1169(99)00041-2

7. (a) M. Bagherzadeh, R. Latifi, L. Tahsini, V. Amani, A. Ellern, L. K. Woo, Polyhedron 2009, 28, 2517-2521;

DOI:10.1016/j.poly.2009.05.036

(b) Z. Moradi-Shoeili, M. Zare, M. Bagherzadeh, M. Kubicki,

D. M. Boghaei, J. Coord. Chem. 2015, 68, 548-559;

DOI:10.1080/00958972.2014.993321

(c) M. Bagherzadeh, M. Amini, H. Parastar, Inorg. Chem. Commun. 2012, 20, 86-89; DOI:10.1016/j.inoche.2012.02.023

(d) A. A. A. Aziz, J. Mol. Struct. 2010, 979, 77-85;

DOI:10.1016/j.molstruc.2010.06.004 (e) R. D. Chakravarthy, K. Suresh, V. Ramkumar, D. K. Chand, Inorg. Chim. Acta 2011, 376, 57-63; DOI:10.1016/j.ica.2011.05.033

(f) S. Rayati, N. Rafiee, A. Wojtczak, Inorg. Chim. Acta 2012, 386, 27-35. DOI:10.1016/j.ica.2012.02.005

8. X. W. Zhu, Russ. J. Coord. Chem. 2018, 44, 421-424. DOI:10.1134/S1070328418070084

9. (a) H. Petek, C. Albayrak, M. Odabasoglu, I. Senel, O. Buyukgungor, Struct. Chem. 2010, 21, 681-690;

DOI:10.1007/s11224-010-9598-6

(b) B. Chattopadhyay, S. Basu, P. Chakraborty, S. K. Choudhuri, A. K. Mukherjee, M. Mukherjee. J. Mol. Struct. 2009, 932, 90-96. DOI:10.1016/j.molstruc.2009.05.047

10. Bruker, SMART (Version 5.625) and SAINT (Version 6.01). Bruker AXS Inc., Madison, Wisconsin, USA, 2007.

11. G. M. Sheldrick, SADABS. Program for Empirical Absorption Correction of Area Detector, University of Göttingen, Germany, 1996.

12. G. M. Sheldrick, SHELXTL V5.1 Software Reference Manual, Bruker AXS, Inc., Madison, Wisconsin, USA, 1997.

13. W. F. Brill, J. Am. Chem. Soc. 1963, 85, 141-145.

DOI:10.1021/ja00885a006

14. (a) S. N. Rao, K. N. Munshi, N. N. Rao, M. M. Bhadbhade, E. Suresh, Polyhedron 1999, 18, 2491-2497;

DOI:10.1016/S0277-5387(99)00139-4

(b) S. M. El-Medani, M. M. Aboaly, H. H. Abdalla, R. M. Ramadan, Spectrosc. Lett. 2004, 37, 619-632.

DOI:10.1081/SL-200037610

15. (a) Q. Liu, J. Lin, J. Liu, W. Chen, Y. Cui, Acta Chim. Slov. 2016, 63, 279-286;

(b) M. Liang, D.-H. Zou, Acta Chim. Slov. 2016, 63, 180-185; DOI:10.17344/acsi.2015.2169

(c) Y. Sui, X. Zeng, X. Fang, X. Fu, Y. Xiao, L. Chen, M. Li, S. Cheng, J. Mol. Struct. A 2007, 270, 61-67.

\section{Povzetek}

Sintetizirali smo dva strukturno sorodna nova dioksomolibdenova(VI) kompleksa, $\left[\mathrm{MoO}_{2} \mathrm{~L}^{1}(\mathrm{EtOH})\right] \cdot \mathrm{EtOH}(\mathbf{1})$ in $\left[\mathrm{MoO}_{2} \mathrm{~L}^{2}(\mathrm{MeOH})\right](2)$, kjer sta $\mathrm{L}^{1}$ in $\mathrm{L}^{2}$ dianionski obliki 2-[(2-hidroksifenilimino)metil]-6-metoksifenola $\left(\mathrm{H}_{2} \mathrm{~L}^{1}\right)$ in 2-etoksi-6-[(2-hidroksifenilimino)metil]fenola $\left(\mathrm{H}_{2} \mathrm{~L}^{2}\right)$, ter ju okarakterizirali $\mathrm{z}$ IR in UV-Vis spektroskopijo, kakor tudi z monokristalno rentgensko difrakcijo. Strukturna analiza je razkrila, da sta oba kompleksa dioksomolibdenovi(VI) zvrsti. Kompleks 1 vsebuje kot ligand tudi molekulo etanola, kompleks 2 pa molekulo metanola. Koordinacijsko geometrijo okoli Mo atomov lahko opišemo kot popačen oktaeder z enim imino $\mathrm{N}$-atomom, dvema fenolatnima O-atomoma in eno okso skupino, ki skupaj definirajo ekvatorialno ravnino, ter drugo okso skupino in molekulo topila, ki zasedata aksialni legi. Proučili smo tudi katalitične lastnosti kompleksov pri reakcijah oksidacije s terc-butilhidroperoksidom $\mathrm{v} \mathrm{CH}_{2} \mathrm{Cl}_{2}$. Oba kompleksa izkazujeta odlične katalitične lastnosti v primeru ciklooktena in cikloheksena ter dobre lastnosti v primeru 1-heksena in 1-oktena. 